\title{
Eating disorders in childhood and adolescence
}

\author{
Transtornos alimentares na infância e na adolescência \\ Trastornos alimentares en la infancia y adolescencia y factores de riesgo
}

Juliana de Abreu Gonçalves ${ }^{1}$, Emilia Addison M. Moreira², Erasmo Benício S. de M. Trindade ${ }^{3}$, Giovanna Medeiros R. Fiates ${ }^{4}$

\section{ABSTRACT}

Objective: To discuss eating disorders in children and adolescents regarding their characteristics and risk factors.

Data sources: Articles were searched in the PubMed and ScieLO databases, combining the terms 'children', 'adolescents', 'eating behavior', 'eating disorder', 'bulimia', and 'anorexia', both in Portuguese and in English. Studies published between 2007 and 2011 were retrieved and 49 articles that assessed eating behavior and disorders, nervous anorexia and bulimia, and non-specific eating disorders were selected.

Data synthesis: Eating disorders, especially non-specific ones, were common during childhood and adolescence. The presence of such disorders was attributed mainly to family environment and exposure to the media. Eating disorders were frequently followed by psychological comorbidities.

Conclusions: Among the risk factors for eating disorders, social and family environment and the media were the most important ones. The influence of the media and social environment has been related to the worship of thinness. As to family environment, mealtimes appeared to be fundamental in shaping eating behavior and the development of disorders. Eating disorders were associated with nutritional problems (growing impairment and weight gain), oral health (cheilitis, dental erosion, periodontitis, and hypertrophy of salivary glands), and social prejudice.
Key-words: feeding behavior; food habits; anorexia; bulimia; child; adolescent.

\section{RESUMO}

Objetivo: Discutir os transtornos alimentares em crianças e adolescentes quanto às suas características e fatores de risco.

Fontes de dados: A pesquisa de artigos foi realizada nas bases de dados PubMed e SciELO pela combinação dos termos 'crianças', 'adolescentes', 'comportamento alimentar', 'transtorno alimentar', 'bulimia' e 'anorexia', nos idiomas português e inglês. Foram considerados os artigos publicados entre 2007 e 2011, sendo selecionados 49 que analisaram o desenvolvimento do comportamento alimentar e de seus transtornos, a anorexia e a bulimia nervosa e os transtornos alimentares não especificados.

Síntese dos dados: Os transtornos alimentares, em especial os não especificados, mostraram-se comuns na infância e na adolescência. Sua presença foi atribuída principalmente ao ambiente familiar e à exposição aos meios de comunicação. As comorbidades psicológicas muitas vezes acompanhavam o diagnóstico do transtorno.

Conclusões: Dentre os fatores de risco para os transtornos alimentares, destacaram-se a mídia e os ambientes social e familiar. A influência da mídia e do ambiente social foi associada, principalmente, ao culto à magreza. Já no âmbito familiar, o momento das refeições mostrou-se fundamental na determinação do comportamento alimentar e no desenvolvimento de
Instituição: Universidade Federal de Santa Catarina (UFSC), Florianópolis, SC, Brasil

${ }^{1}$ Graduanda em Nutrição; Bolsista do Programa Especial de Treinamento (PET) em Nutrição, UFSC, Florianópolis, SC, Brasil

Doutora em Ciência dos Alimentos pela Faculdade de Ciências Farmacêutica da Universidade de São Paulo (USP); Professora do Departamento de Nutrição e Programa de Pós-Graduação em Nutrição da UFSC, Florianópolis, SC, Brasil

${ }^{3}$ Doutor em Doenças Tropicais pela Faculdade de Medicina de Botucatu, Universidade Estadual Paulista "Júlio de Mesquita Filho" (UNESP/Botucatu); Professor do Departamento de Nutrição e Programa de Pós-Graduação em Nutrição da UFSC, Florianópolis, SC, Brasil

${ }^{4}$ Doutora em Ciência dos Alimentos pela UFSC; Professora do Departamento de Nutrição e Programa de Pós-Graduação em Nutrição da UFSC e Tutora do PET Nutrição, UFSC, Florianópolis, SC, Brasil
Endereço para correspondência:

Emilia Addison M. Moreira

Departamento de Nutrição, Centro de Ciências da Saúde, UFSC, Campus Universitário, Trindade, $\mathrm{s} / \mathrm{n}$

CEP 88040-970 - Florianópolis/SC

E-mail: addison@ccs.ufsc.br

Conflito de interesse: nada a declarar

Recebido em: 19/12/2011

Aprovado em: 14/5/2012 
seus transtornos. Os transtornos alimentares se associaram a problemas nutricionais (déficit no crescimento e ganho de peso), à saúde bucal (queilose, erosão dental, periodontites e hipertrofia das glândulas salivares) e aos prejuízos sociais.

Palavras-chave: comportamento alimentar; hábitos alimentares; anorexia; bulimia; criança; adolescente.

\section{RESUMEN}

Objetivo: Discutir los trastornos alimentares en niños y adolescentes respecto a sus características y factores de riesgo.

Fuentes de datos: La investigación de artículos se realizó en las bases de datos PubMed y SciELO por la combinación de los términos "niños", "adolescentes", "comportamiento alimentar", "trastorno alimentar", "bulimia" y "anorexia”, en los idiomas portugués e inglés. Se consideraron los artículos publicados entre 2007 y 2011, siendo seleccionados 49 que analizaron el desarrollo del comportamiento alimentar y de sus trastornos, la anorexia y la bulimia nerviosa y los trastornos alimentares no especificados.

Síntesis de los datos: Los trastornos alimentares, en especial los no especificados, se mostraron comunes en la infancia y en la adolescencia. Su presencia fue asignada principalmente al ambiente familiar y a la exposición a los medios de comunicación. Las comorbilidades psicológicas muchas veces acompañan el diagnóstico del trastorno.

Conclusiones: Entre los factores de riesgo para los trastornos alimentares, se destacan los medios y los ambientes social y familiar. La influencia de los medios y del ambiente social fue asociada, principalmente, al culto a la delgadez. En el ámbito familiar, a su vez, el momento de la comida se mostró fundamental en la determinación del comportamiento alimentar y en el desarrollo de sus trastornos. Los trastornos alimentares se asociaron a problemas nutricionales (déficit en el crecimiento y ganancia de peso), a la salud oral (queilosis, erosión dental, periodontitis e hipertrofia de las glándulas salivares) y a los perjuicios sociales.

Palabras clave: comportamiento alimentar; hábitos alimentare; anorexia; bulimia; niño; adolescente.

\section{Introduction}

Eating behavior is defined as "sequential or behavioral answers associated with the act of eating, manner or mode of eating, rhythmic patterns of feed" ${ }^{\prime \prime}$. Such behavior is influenced by social, demographic and cultural conditions, by the individual perception, the food, previous experiences and the nutritional status ${ }^{(2)}$.

Among these factors, the socio-cultural impact on dietary intake and the development of eating disorders (ED) has been more frequently studied, assessing the family customs ${ }^{(3-6)}$ and the information conveyed by the mass media ${ }^{(7-10)}$.

The influence of the media, magnified by globalization and society, was described by Anschutz et al $l^{(7)}$ and Oliveira and Hutz ${ }^{(11)}$, who emphasize the contradiction between the appeal for healthy lifestyle at the same time that it is praised the cult of thinness and it is encouraged the consumption of high-calorie foods.

The result of these contradictions is the development of $\mathrm{ED}$, characterized by an exaggerated concern with weight and shape ${ }^{(11)}$. In pursuit of this stereotype, weight loss is induced by inadequate methods, like fasting and intense physical exercise, and gain muscle mass is stimulated by excessive workouts, improper diet and the use of anabolic steroids ${ }^{(12)}$.

Eating disorders are related to clinical complications that vary according to the characteristics of the disorder, occurring stunted growth ${ }^{(13)}$, cheilosis, dental erosion, periodontitis, salivary gland hypertrophy, hypovolemia, electrolyte imbalance and weight gain ${ }^{(14)}$.

When the beginning of ED occurs during adolescence, such disorders affect social and family relationships, and suicidal ideation becomes more common ${ }^{(11,15)}$. The onset of sexual activity before 16 years-old is also more frequent in adolescents with eating disorders. Moreover, young women with a history of ED have higher chances of abortion or pregnancy ${ }^{(16)}$.

Thus, this study aimed to discuss the characteristics and the risk factors associated with eating disorders in children and adolescents.

\section{Data Sources}

The search for articles was performed in PubMed and SciELO databases, combining the terms 'children', 'adolescents', 'eating behavior', 'eating disorder', 'bulimia' and 'anorexia', both in Portuguese and in English. We considered articles published between 2007 and 2011, and 49 of them were selected. They analyzed the development of eating behavior and its disorders, the anorexia nervosa (AN), the bulimia nervosa $(\mathrm{BN})$ and non-specific ED.

\section{Development of eating behavior and its disorders}

The comprehension of eating behavior requires questioning and reflection on the following question: "Who eats what, 
when, where, and why?". The discussion that arises from this question is based on psychological and health issues, besides those involving socioeconomic factors, as well as marketing ${ }^{(2)}$.

Studies have shown the influence of family environment to determine the behavior of children and adolescents ${ }^{(3-5)}$ and, consequently, the development of their disorders, for which the child or the adolescent has a high concern with weight and body shape ${ }^{(12)}$. This relationship was evident in an European multicentre study developed with 1,664 children and adolescents. This research showed a negative association between the maintenance of a healthy diet and the subsequent development of eating disorders, and a positive relationship between excessive control, the application of strict dietary rules and the individualization of food with the emergence of $\mathrm{ED}^{(3)}$.

The individualization of meals by family members with consumption of different foods in different places and times $^{(5)}$ - may be the result of excessive activities among adolescents $^{(3)}$ or the eating disorder within the family ${ }^{(5)}$. These findings are consistent with those observed in a study of 10,540 pre-adolescent girls. In this study, the habit of dining with family, on most days, was negatively associated to the first use of purging methods, the binge eating disorder and diets ${ }^{(4)}$. About the family environment, a work showed that there was a greater internalization of the ideal beauty by children when mothers encouraged weight $\operatorname{loss}^{(7)}$.

The mass media have a strong influence on eating behavior in children ${ }^{(6)}$, as well as in adolescents ${ }^{(10)}$. The role of the media, ideal beauty and fashion industry in the development of ED is not clear ${ }^{(7,9)}$. In this context, a study of 245 pre-adolescent girls showed a positive relationship between the habit of watching soap operas and music channels with food restriction and body dissatisfaction, and negative relationship between the habit of watching cartoons and food restriction ${ }^{(7)}$. Another research among 7,172 adolescents found an association between the desire to appear as a media figure of the same sex with the start of purging behaviors ${ }^{(17)}$.

As for boys, eating attitudes and disorders are also associated with the evolution of weight, psychosocial well-being promoted by food ${ }^{(18)}$ - , the strong appeal of socio-cultural worship of thinness ${ }^{(10)}$, the social group to which one belongs ${ }^{(19)}$, besides socioeconomic ${ }^{(10,20,21)}$ and psychological ${ }^{(7)}$ factors.

Eating disorders are more often found in women ${ }^{(22,23)}$. Some risk factors for the development of these disorders become more prevalent with the increase in body mass index (BMI), as well as low self-esteem, dieting, interceptive deficits, fear of maturity and body dissatisfaction ${ }^{(22)}$. The concern with weight $^{(22)}$, diets, weight-related teasing ${ }^{(17,24)}$ and obsessivecompulsive disorder ${ }^{(23)}$ are also associated with ED symptoms.

Recently, a research of 53 women aged between 14 and 44 years-old, diagnosed with diabetes mellitus type 1, also showed that there is a relationship between this disease and the development of disorders such as anorexia nervosa and bulimia nervosa. The authors concluded that women diagnosed with diabetes mellitus type 1, aged from 7 to 18 years-old, were more likely to develop $\mathrm{ED}^{(25)}$.

Risk factors for the development of eating disorders were studied in 652 female adolescents. Among the girls that were evaluated, $25.2 \%$ of them were at risk, and $1.2 \%$ showed high possibility of developing ED. The desire to lose weight was prevalent in $44.5 \%$ of the adolescents, and $50.5 \%$ wished to be classified below the ideal weight, according to the BMI. In this study, although the desire for weight loss was independent from socioeconomic status, the prevalence of risk behaviors was superior among individuals belonging to the higher strata ${ }^{(26)}$.

\section{Anorexia nervosa and bulimia nervosa}

Among the diseases of unknown etiology that interrelate with each other, there are the AN and the BN. They are both characterized by abnormal patterns of eating behavior, weight control and altered perceptions about weight and body ${ }^{(27,28)}$.

In these kind of eating disorders, the concern with food is common. In the study of Nunes and Vasconcelos, for seven adolescents with $\mathrm{AN}$ and $\mathrm{BN}$, eating would refer to something negative, such as torture, fear and obligation. Still in the same study, food consumption was characterized by the restriction of "junk foods", e.g. chocolates and candies, and by the increased intake of vegetables and soft drinks ${ }^{(29)}$.

Anorexia is an eating disorder characterized for the desire for thinness, what leads to dull and ritualized food behavior ${ }^{(27)}$, and a significant weight loss, especially in children or adolescents in whom low caloric intake is reflected in developmental delay ${ }^{(12)}$.

The criteria for diagnosing anorexia, defined in the Diagnostic and Statistical Manual of Mental Disorders - IV (DSM-IV), include: amenorrhea, weight below $85 \%$ of the minimum expected for age and height, disturbances in recognition of own weight and intense fear of weight gain ${ }^{(12,27)}$.

The restrictive anorexia nervosa limits energy intake and the consumption of carbohydrates and lipids ${ }^{(27)}$, while in the purgative one, frequent episodes of binge eating and purga$\operatorname{tion}^{(30)}$ occur. The purging behaviors are the use of laxatives, diuretics and enemas, and induced vomiting ${ }^{(12)}$. 
The psychological state, in this clinical condition, has been studied in a representative sample of adolescents in the United States. The authors concluded that there was no correlation between the AN and mental comorbidities, except for the 'oppositional defiant disorder'. Once mental comorbidities are highly prevalent in anorexic adults, the study suggested that the occurrence of ED in adolescence may be a causal factor of such comorbidities in adulthood. In the same research, it was found a statistically significant relationship between $\mathrm{BN}$ and depression, bipolar disorder, anxiety related disorders - such as social phobia and posttraumatic stress -, besides behavioral disorders, e.g. hyperactivity, attention deficit and conduct disorders ${ }^{(15)}$.

The relationship between anorexia and bulimia has been reported in literature ${ }^{(30-32)}$. A prospective study of 2,881 adolescents showed that the previous diagnosis of $\mathrm{AN}$ and $\mathrm{BN}$ was present in $24 \%$ of patients with subclinical BN, and in $31 \%$ of those with clinical $\mathrm{BN}^{(32)}$.

The bulimic also feel a great fear of gaining weight ${ }^{(27)}$, and often has a distorted view of one's own body ${ }^{(27,33,34)}$. These individuals also tend to restrict their food intake, but after some time following a restrictive diet, they lose control and have binge eating episodes ${ }^{(12,27)}$. After the binge, the bulimic tries to compensate the high caloric intake ${ }^{(12)}$.

Bulimia nervosa can be classified according to the compensatory method, adopted in purging or non-purging ${ }^{(12.27)}$. The non-purging subtype is characterized by intense physical activity or by fasting ${ }^{(12)}$, whereas the purging one, more prevalent in the study of Keski-Rahkonen et l $^{(32)}$, characterizes by induced vomiting or laxative and diuretics abuse ${ }^{(12)}$. According to DETM-IV, someone is only diagnosed with BN if he/she presents binge and compensation episodes twice a week for at least three months ${ }^{(12,27)}$.

Bulimia was found most frequently in the age group from 16 to 20 years-old $^{(32)}$. The authors noted that, due to the similarity between bulimic and non-bulimic BMI and weight maintenance, the person can hide the disorder for several years ${ }^{(32)}$.

The use of substances that cause addiction are also relevant in adolescents with eating disorders. A prospective study with 999 adolescents found that those who had subclinical $\mathrm{AN}$ and $\mathrm{BN}$ cases were twice as likely to reach adulthood depending nicotine, with disorders related to alcohol or amphetamines ${ }^{(16)}$. Another research showed a positive relationship between the use of substances that cause addiction, during adolescence, in clinical cases of $\mathrm{BN}^{(15)}$. Finally, a study observed a weak — but positive - connection between alcohol consumption and smoking with diets, binge eating and extreme behaviors for weight loss ${ }^{(19)}$.

Even though both diseases normally begin during adolescence, for some authors, anorexia can be found from seven years of age $\mathrm{e}^{(35)}$. They point out that $\mathrm{AN}$, in childhood, can affect or even stop physical development, and that the incidence in boys may be higher before puberty. On the other hand, $\mathrm{BN}$ is rare before adolescence ${ }^{(35)}$.

The incidence of $\mathrm{AN}$ and $\mathrm{BN}$ in childhood is unknown, due to the tendency to group children and adolescents ${ }^{(35)}$. In adolescence, a study found prevalence of $\mathrm{AN}$ equal to $0.3 \%$, and of $\mathrm{BN}$ equal to $0.9 \%$, and such disturbances started on average with 12.3 and 12.4 years-old, respectively. Although apparently these prevalences are low, it should be noted that these data may be underestimated because of the refusal of individuals with disorders to participate in researches ${ }^{(15)}$.

In Brazil, there are few works that determine prevalence of ED in children and adolescents. In 2008, a study, conducted in Florianopolis, of 1,219 girls from 10 to 19 years-old showed a prevalence of $A N$ of $15.6 \%$, and $18.8 \%$ of body dissatisfaction. Furthermore, the presence of AN had statistically significant relationship with body dissatisfaction, overweight and obesity in those who studied in public schools and aged between 10 and 13 years-old ${ }^{(36)}$. Also in the same city, another study of 258 girls found a prevalence of $25.3 \%$ of body dissatisfaction, and symptoms of $\mathrm{AN}$ and $\mathrm{BN}$ of $27.6 \%{ }^{(37)}$.

\section{Non-specific eating disorders}

Non-specific ED (EDNOS) are the clinically relevant ones that do not meet criteria for $\mathrm{AN}$ or $\mathrm{BN}^{(38)}$. Although its prevalence is higher than that of $\mathrm{AN}$ or $\mathrm{BN}^{(39)}$, the knowledge about prevalences, risk factors, clinical correlations and treatment of such disorders is limited ${ }^{(38)}$.

Among EDNOS, there are the subclinical AN and BN, binge eating (clinical or subclinical), purgation (clinical or subclinical) and others, which include EDNOS that do not fit into the described subtypes ${ }^{(39)}$.

The frequency of EDNOS in a sample of 281 adolescents referred for treatment of ED was $59.1 \%$, which shows the clinical and epidemiological importance of these disorders. In this study, $16.4 \%$ of adolescents were diagnosed with purging disorder, $16.4 \%$ with subclinical $\mathrm{AN}, 11.7 \%$ with subclinical BN, and $2.1 \%$ with binge eating. Other types of EDNOS had a prevalence of $11 \%$, with cases of purgation, exaggerated practice of exercises and 24 hours fasting. The research showed that $67.4 \%$ of patients with subclinical AN were not diagnosed because of the absence of amenorrhea, 
and the remaining ones for weighing between 86 and 90\% below the ideal minimum for age and height. Regarding the subclinical BN, $73.5 \%$ of patients did not complete the criteria, due to the lower frequency of binge eating episodes ${ }^{(39)}$.

Binge eating is a EDNOS that is characterized by ingestion of a greater amount of food that most people ingest in a small time interval, at least twice a week, for six consecutive months, accompanied by a feeling of lack of self-control ${ }^{(40)}$. During these episodes, individuals feel a loss of control over what or how much they eat and, in the end, they feel guilty and depressed ${ }^{(40)}$. Unlike the BN, during the binge eating, methods to compensate the excessive amount of food eaten are not used ${ }^{(41)}$. Although it often does not complete the diagnostic criteria defined for adults, the binge eating is common in children, especially in the obese ones ${ }^{(35,42)}$. Subclinical cases of such disorder can also occur, in which the feeling of lack of self-control is present in the absence of an excessive consumption ${ }^{(43)}$.

In a study with adolescents, the prevalence of clinical cases of binge eating was $1.6 \%$, and of subclinical ones, $2.5 \%$. Both of them had the median age of the first symptoms in 12.6 years ${ }^{(15)}$.

Psychological stress may be associated with the development of binge eating ${ }^{(24,42)}$. The negative affect and provocations based on weight were related with this disorder in a study of 265 twin sisters. The authors suggested that 'provocations' were the causes of negative affect, and that this stress would initiate the chain of events that leads to binging ${ }^{(24)}$.

According to the study by Allen $e t$ al ${ }^{(42)}$, food restriction, low self-esteem, depression and concern with weight, body and food are more prevalent in children with binge eating. The relationship between these symptoms and binge eating is directly related to the severity of eating disorder, as observed in a study of 350 children and adolescents with overweight ${ }^{(44)}$.

Since the loss of control is one of the main characteristics of EDNOS, only a few investigations have exclusively addressed this aspect ${ }^{(43,45)}$. The study of 120 children - with and without loss of control over food - showed that those with low control over food were more impulsive and had lower self-orientation, low cooperativeness and higher demand for novelty ${ }^{(46)}$.

The dietary intake of these people has also attracted the interest of some authors. When comparing 59 compulsive children with a Control Group, it was observed that the consumption of carbohydrates and lipids was higher during binge episodes than during normal meals of the Control Group ${ }^{(47)}$. A study of 249 children and adolescents showed that there has only been an increase in the carbohydrate consumption, with higher consumption of snacks and desserts ${ }^{(48)}$.
Assessing 259 children, researchers also found that, in EDNOS, there is a relationship between dietary intake and mood, i.e., it was common to use food intake to regulate $\operatorname{mood}^{(42)}$. However, another study of 46 girls from 6 to 12 yearsold with overweight showed no relationship between consumption and binge eating and between consumption and mood after control variable, according to $\mathrm{BMI}^{(49)}$. For other authors, the loss of control was not preceded by negative emotions and negative mood states were not observed after the binge episode ${ }^{(47)}$.

The purging disorder is a poorly studied ED. In it, the person uses purging behaviors such as vomiting and the use of laxatives and diuretics, without the binge eating necessarily preceding the purgation. In clinical cases, the episodes occur on average twice per week for three months; in subclinical cases, there is not a frequency and duration criterion ${ }^{(39)}$.

Great attention has also been given to subclinical cases of anorexia and bulimia, because in addition to being more prevalent than specific disorders ${ }^{(15)}$, studies show that, despite not fulfilling the criteria for the diagnosis of specific disorder or not being persistent, these cases are characterized by the same markers of severity than clinical cases of AN and $\mathrm{BN}^{(15,16,28,39)}$.

A comparative summary of the analyzed studies, with its main findings regarding the characteristics of the disorder and eating behavior in children and adolescents, identified a similarity between age, cause of the disorder and consequences (Table 1).

We discovered few national studies on eating disorder in this study. Considering the importance of the social environment in the development of ED and the specific socio-cultural realities, risk factors found in the works may not apply to the Brazilian case. Also, studies that discussed EDNOS - whether national or international - were rare, which may have limited the debate around the topic.

\section{Conclusions}

Among the risk factors for eating disorders, the most significant were the media and the social and family environments. The influence of the media and the social environment was associated, mainly, to the worship of thinness, while in the family, the timing of the meals was essential in determining the eating behavior and the development of disorders. The ED were associated with nutritional problems (stunted growth and weight gain), oral health (cheilosis, dental erosion, periodontitis and salivary gland hypertrophy) and social harm. 


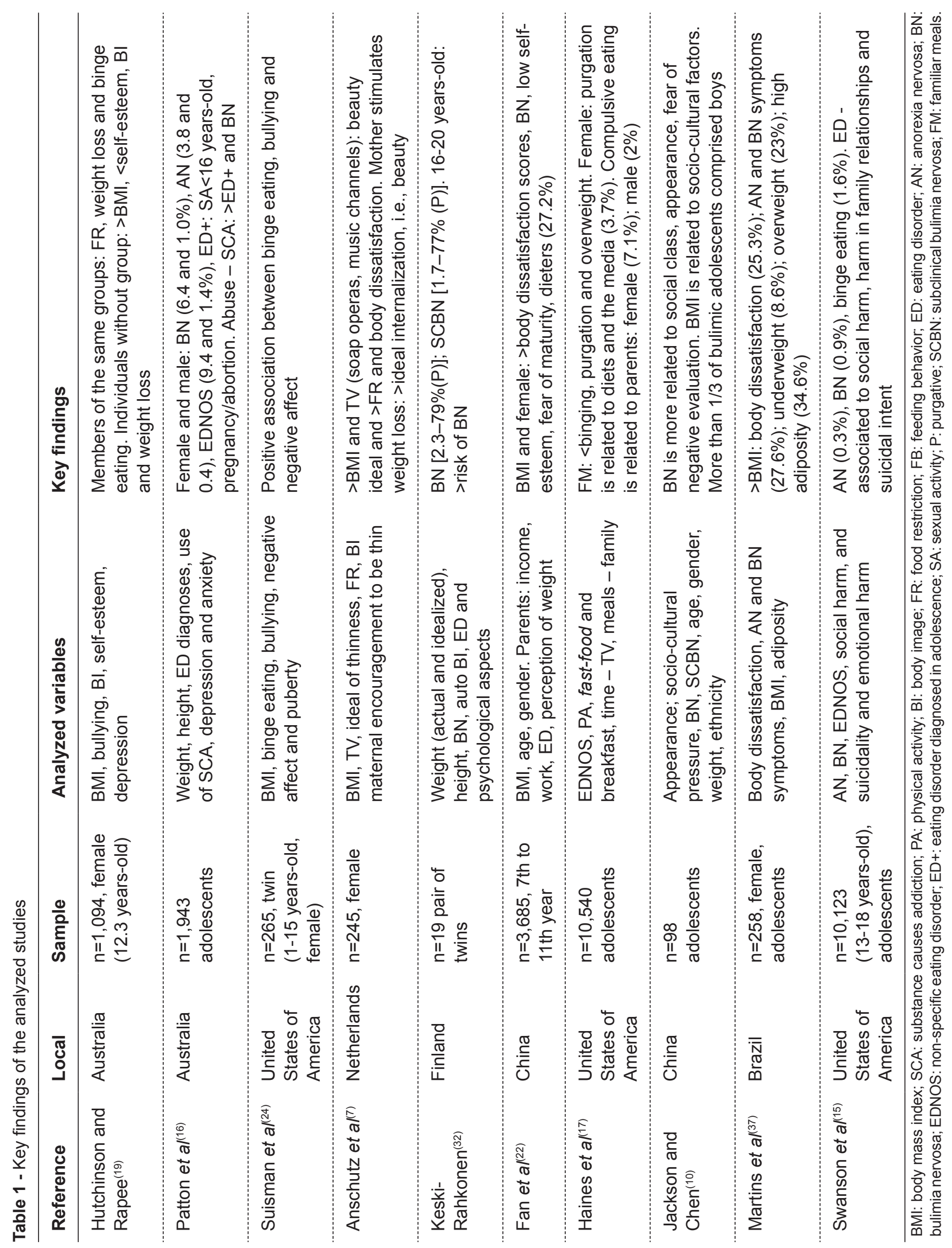




\section{References}

1. BVS [homepage on the Internet]. São Paulo: Descritores em ciências da saúde [cited 2011 Sep 18]. Available from: http://decs.bvs.br/

2. Köster EP. Diversity in the determinants of food choice: a psychological perspective. Food Qual Prefer 2009;20:70-82.

3. Krug I, Treasure J, Anderluh M, Bellodi L, Cellini E, Collier D et al. Associations of individual and family eating patterns during childhood and early adolescence: a multicentre European study of associated eating disorder factors. Br J Nutr 2009;101:909-18.

4. Haines J, Gillman MW, Rifas-Shiman S, Field AE, Austin SB. Family dinner and disordered eating behaviors in a large cohort of adolescents. Eat Disord 2010;18:10-24.

5. Kime N. Children's eating behaviours: the importance of the family setting. Area 2008;40:315-22.

6. Rossi A, Moreira EA, Rauen MS. Determinants of eating behavior: a review focusing on the family. Rev Nutr 2008;21:739-48.

7. Anschutz D, Engels R, Leeuwe JV, Strien J. Watching your weight? The relations between watching soaps and music television and body dissatisfaction and restrained eating in young girls. Psychol Health 2009;24:1035-50.

8. Pereira CS. Os wannabees e suas tribos: adolescência e distinção na internet. Rev Estud Fem 2007;15:357-82.

9. Kelly B, Halford JC, Boyland EJ, Chapman K, Bautista-Castaño I, Berg C et al. Television food advertising to children: a global perspective. Am J Public Health 2010;100:1730-6.

10. Jackson T, Chen H. Sociocultural experiences of bulimic and non-bulimic adolescents in a school-based chinese sample. J Abnorm Child Psychol 2010;38:69-76

11. Oliveira LL, Hutz CS. Eating disorders: the role of cultural aspects in the contemporary world. Psicol Estud 2010;15:575-82.

12. Herpertz-Dahlmann B. Adolescent eating disorders: definitions, symptomatology, epidemiology and comorbidity. Child Adolesc Psychiatr Clin N Am 2009;18:31-47.

13. Eckhardt SM, Ahmed SF. Linear growth in anorexia nervosa. J Pediatr Gastroenterol Nutr 2010;51 (Suppl 3):S127-8.

14. Mehler PS. Medical complications of bulimia nervosa and their treatments. Int J Eat Disord 2011;44:95-104.

15. Swanson SA, Crow SJ, Le Grange DL, Swendsen J, Merikangas KR. Prevalence and correlates of eating disorders in adolescents. Results from the national comorbidity survey replication adolescent supplement. Arch Gen Psych 2011;68:714-23.

16. Patton GC, Coffey C, Carlin JB, Sanci L, Sawyer S. Prognosis of adolescent partial syndromes of eating disorder. Br J Psychiatry 2008;192:294-9.

17. Haines J, Kleinman KP, Rifas-Shiman SL, Field AE, Austin SB. Examination of shared risk and protective factors for overweight and disordered eating among adolescents. Arch Pediatr Adolesc Med 2010;164:336-43.

18. Viana V, Santos PL, Guimarães MJ. Eating behavior and food habits in children and adolescents: a literature review. Psic Saude Doenças 2008;9:209-31.

19. Hutchinson DM, Rapee RM. Do friends share similar body image and eating problems? The role of social networks and peer influences in early adolescence. Behav Res Ther 2007;45:1557-77.

20. Bau AM, Krull S, Ernert A, Babitsch B. Eating behaviour and its association with social living conditions and weight status among adolescent girls: results of the cross-sectional Berlin School Children's Cohort study. Public Health Nutr 2011;14:1759-67.

21. Skidmore P, Welch A, van Sluijs E, Jones A, Harvey I, Harrison F et al. Impact of neighbourhood food environment on food consumption in children aged 9-10 years in the UK SPEEDY (sport, physical activity and eating behavior: environmental determinants in young people) study. Public Health Nutr 2009;13:1022-30.

22. Fan Y, Li Y, Liu A, Hu X, Ma G, Xu G. Associations between body mass index, weight control concerns and behaviors, and eating disorder symptoms among non-clinical Chinese adolescents. BMC Public Health 2010;10:314.
23. Micali N, Hilton K, Natatani E, Heyman I, Turner C, Mataix-Cols D. Is childhood $\mathrm{OCD}$ a risk factor for eating disorders later in life? A longitudinal study. Psychol Med 2011;7:1-7.

24. Suisman JL, Slane JD, Burt SA, Klump KL. Negative affect as a mediator of the relationship between weight-based teasing and binge eating in adolescent girls. Eat Behav 2008;9:493-6.

25. Takii M, Uchigatab Y, Kishimoto J, Morita C, Hata T, Nozaki T et al. The relationship between the age of onset of type 1 diabetes and the subsequent development of a severe eating disorder by female patients. Pediatr Diabetes 2011;12:396-401.

26. Do Vale AM, Kerr LR, Bosi ML. Risk behaviors for eating disorders among female adolescents from different social strata in the Brazilian Northeastern. Cienc Saude Colet 2011;16:121-32.

27. Kaye W. Neurobiology of anorexia and bulimia nervosa purdue ingestive behavior research center symposium influences on eating and body weight over the Lifespan: children and adolescents. Physiol Behav 2008;94:121-35.

28. Dixe MA. Prevalência das doenças do comportamento alimentar. Ana Psicol 2007;25:559-69.

29. Nunes AL, Vasconcelos F de A. Eating disorders in the view of teenage girls from Florianópolis, Santa Catarina State: a phenomenological approach. Cienc Saude Colet 2010;15:539-50.

30. Peat C, Mitchell JE, Hoek HW, Wonderlich SA. Validity and utility of subtyping anorexia nervosa. Int J Eat Disord 2009;42:590-4.

31. Vaz-Leal FJ, Rodríguez Santos L, García-Herráiz MA, Monge-Bautista M, López-Vinuesa B. Bulimia nervosa with history of anorexia nervosa: could the clinical subtype of anorexia have implications for clinical status and treatment response? Int J Eat Disord 2011;44:212-9.

32. Keski-Rahkonen A, Hoek HW, Linna MS, Raevuori A, Sihvola E, Bulik CM et al. Incidence and outcomes of bulimia nervosa: a nationwide population-based study. Psychol Med 2009;39:823-31.

33. Mohr HM, Röder C, Zimmermann J, Hummel D, Negele A, Grabhorn R. Body image distortions in bulimia nervosa: investigating body size overestimation and body size satisfaction by fMRI. Neuroimage 2011;56:1822-31.

34. Urgesi C, Fornasari L, De Faccio S, Perini L, Mattiussi E, Ciano R et al. Body schema and self-representation in patients with bulimia nervosa. Int $\mathrm{J}$ Eat Disord 2011;44:238-48.

35. Nicholls D, Bryant-Waugh R. Eating disorders of infancy and childhood: definition, symptomatology, epidemiology, and comorbidity. Child Adolesc Psych Clin N Am 2009;18:17-30.

36. Alves E, Vasconcelos FA, Calvo MC, Neves J. Prevalence of symptoms of anorexia nervosa and dissatisfaction with body image among female adolescents in Florianópolis, Santa Catarina state, Brazil. Cad Saude Publica 2008;24:503-12.

37. Martins CR, Pelegrini A, Matheus SC, Petroski EL. Body image dissatisfaction and its relationship with nutritional status, body fat, and anorexia and bulimia symptoms in adolescents. Rev Psiquiatr RS 2010;32:19-23.

38. Keel PK, Striegel-Moore RH. The validity and clinical utility of purging disorder. Int J Eat Disord 2009;42:706-19.

39. Eddy KT, Celio Doyle A, Hoste RR, Herzog DB, Le Grange D. Eating disorder not otherwise specified in adolescents. J Am Acad Child Adolesc Psychiatry 2008; $47: 156-64$.

40. Wolfe BE, Baker CW, Smith AT, Kelly-Weeder S. Validity and utility of the current definition of binge eating. Int J Eat Disord 2009;42:674-86.

41. Keel PK, Holm-Denoma JM, Crosby RD. Clinical significance and distinctiveness of purging disorder and binge eating disorder. Int J Eat Disord 2011;44:311-6.

42. Allen KL, Byrne SM, La Puma M, McLean N, Davis EA. The onset and course of binge eating in 8- to 13-year-old healthy weight, overweight and obese children. Eat Behav 2008;9:438-46.

43. Goldschmidt AB, Jones M, Manwaring JL, Luce KH, Osborne MI, Cunning $\mathrm{D}$ et al. The clinical significance of loss of control over eating in overweight adolescents. Int J Eat Disord 2008;41:153-8. 
44. Goossens L, Braet C, Bosmans G. Relations of dietary restraint and depressive symptomatology to loss of control over eating in overweight youngsters. Eur Child Adolesc Psych 2010;19:587-96.

45. Czaja J, Rief W, Hilbert A. Emotion regulation and binge eating in children. Int J Eat Disorder 2009;42:356-62.

46. Hartmann AS, Czaja J, Rief W, Hilbert A. Personality and psychopathology in children with and without loss of control over eating. Compr Psych 2010;51:572-8.
47. Hilbert A, Rief W, Tuschen-Caffier B, de Zwaan M, Czaja J. Loss of control eating and psychological maintenance in children: an ecological momentary assessment study. Behav Res Ther 2009;47:26-33.

48. Theim KR, Tanofsky-Kraff M, Salaita CG, Haynos AF, Mirch MC, Ranzenhofer LM et al. Children's descriptions of the foods consumed during loss of control eating episodes. Eat Behav 2007;8:258-65.

49. GoldschmidtAB, Tanofsky-Kraff M, Wilfley DE. A laboratory-based study of mood and binge eating behavior in overweight children. Eat Behav 2011;12:37-43. 